\title{
Experimental lagochilascariosis in X-chromosome-linked immunodeficient mice
}

\author{
Lagochilascariose experimental em camundongos com \\ imunodeficiência ligada ao cromossomo X
}

\author{
Jaqueline Aparecida Gleice de Freitas ${ }^{1}$, Mariana Félix de Souza Prudente ${ }^{1}$ \\ and Mara Silvia Carvalhaes ${ }^{1}$
}

\begin{abstract}
Lagochilascaris minor is the etiological agent of lagochilascariosis, a disease that affects the neck region and causes exudative abscesses, with eggs, adult parasites and L/L4 larvae in the purulent exudates. Mice are now considered to be intermediate hosts for the parasite. To determine the pattern of infection in B1 cell-deficient mice, experimental lagochilascariosis was studied in BALB/c and X-chromosome-linked immunodeficient (xid) mice. BALB.xid-infected mice showed lower numbers of larvae. Third-stage larvae, fourth-stage larvae and adult parasites were found in both strains. BALB/c mice produced IgM, IgG, IgA and IgE against the crude extract and secreted/excreted antigens of the parasite. On the other hand, BALB.xid mice did not produce IgM and produced lower levels of IgG and IgA, and similar quantities of IgE.
\end{abstract}

Key-words: B1 cells. BALB.xid mice. Lagochilascaris minor. Immunoglobulin.

\section{RESUMO}

Lagochilascaris minor é o agente etiológico da lagochilascariose, uma doença que afeta a região de pescoço provocando abscessos exudativos contendo ovos, parasitas adultos e larvas L3/L4 nos exudates purulentos. Atualmente, camundongos são considerados hospedeiros intermediários do parasita. Para determinar o padrão de infecção em camundongos deficientes de células B1, a lagochilascariose experimental foi estudada em camundongos BALB/c e em camundongos com imunodeficiência ligada ao cromossomo X (xid). Camundongos BALB.xid infectados mostraram menor número de larvas. Larvas L3, L4 e parasitas adultos foram encontrados em ambas as linhagens. Camundongos BALB/c produziram IgM, IgG, IgA e IgE contra o extrato bruto e antígenos secretados/excretados do parasita; por outro lado, camundongos BALB.xid não produziram IgM, produziram baixos níveis de IgG e IgA, e quantidades semelhantes de IgE.

Palavras-chaves: Células de B1. Camundongos BALB.xid. Lagochilascaris minor. Imunoglobulina.

Human lagochilascariosis is caused by Lagochilascaris minor and it is considered to be an emerging helminthosis. It is limited to the Neotropical area (Mexico to Brazil), but infected cats have been found in Uruguay. The parasitosis is not yet a public health problem, but it is prevalent among individuals of the lowest socioeconomic class, notably in rural areas. The genus Lagochilascaris includes five species: Lagochilascaris minor, Lagochilascaris major, Lagochilascaris buckleyi, Lagochilascaris turgida and Lagochilascaris sprenti. Of these, Lagochilascaris minor is the most important from a medical standpoint, since it is the etiological agent of human lagochilascariosis in South America ${ }^{1}$. Cases of infection have been reported in individuals of both sexes, and in most cases, the lesions

\footnotetext{
1. Department of Microbiology, Immunology, Parasitology and Pathology; Institute of Tropical Pathology and Public Health, Federal University of Goiás, Goiânia, G0, Brazil. Address to: Dr. Mara Silvia Carvalhaes. Immunology Sector, Department of Microbiology, Immunology, Parasitology and Pathology, Institute of Tropical Pathology and Public Health, Federal University of Goiás. Postal Box 1031, 74001-970 Goiânia, GO, Brazil.

Tel: 5562 3209-6109; Fax: 5562 3521-1839

e-mail: msilvia@iptsp.ufg.br

Received in 13/04/2008

Accepted in 12/08/2009
}

have been chronic, affecting neck and head tissues with abscess formation. Sometimes, the parasite invades the pulmonary tissue and, fatally, the central nervous system. Frequently, Lagochilascaris minor lesions contain different stages of the parasite (eggs, larvae and adult worms), thus indicating autoinfection, and this favors the development of chronic disease ${ }^{1}$.

The extraordinary capacity of Lagochilascaris minor to migrate across different human tissues can be also observed in animal models of the disease such as mice and cats. In mice that are orally inoculated with infective parasite eggs, hatched larvae can be observed migrating in the intestinal tract, with third-stage larvae (L3) migrating through the intestinal mucosa to reach vessels and the hepatic parenchyma, and disseminating to other tissues such as the lungs, skeletal muscles and subcutaneous tissues. In cats that eat infected mice, L3 migrate through the esophagus, pharynx, trachea and cervical lymph nodes?.

As demonstrated in the literature, BALB.xid mice present impaired production of B1 lymphocytes. More than 20 years have passed since the discovery of B1 cells, and a large number of studies have been conducted in order to characterize and determine their origin and function. It has been well established that $\mathrm{B} 1$ cells constitute a minor fraction of the B cell population 
in the spleen and are not detected in the lymph nodes of mice. Nevertheless, they represent the main B cell population in the peritoneal and pleural cavities of these animals $s^{6}$. Based on these data, we decided to investigate the parasitological and serological profile of experimental lagochilascariosis in BALB/c and BALB. xid mice. The major focus of this study was the usefulness of immunodeficient BALB.xid and BALB/c mice for evaluations on host-parasite relationships in experimental lagochilascariosis.

\section{MATERIAL AND METHODS}

Animals and parasites. Six to eight-week-old Bruton-tyrosinekinase mutant X-linked immunodeficient (xid) male BALB.xid mice, and their wild-type counterparts (male BALB/c mice), were purchased from the University of São Paulo Animal Facility. They were kept with food and water provision ad libitum and were handled in accordance with the local regulations. The Research Ethics Committee of the Federal University of Goiás approved the research protocols. Eggs from the parasite were collected from feces of Felis domesticus that had been experimentally infected with a human isolate of Lagochilascaris minor. The feces from the infected animals were subjected to Hoffman's and Faust's method, as described by Oliveira et al ${ }^{3}$. The final concentration was adjusted to $10^{4} \mathrm{egg} / \mathrm{ml}$.

Experimental infection design. BALB/c and BALB.xid mice were orally inoculated with a suspension of $10^{3} \pm 200$ Lagochilascaris minor eggs per animal. After inoculation, groups of animals were sacrificed at different time points (five per time point; from 30 to 210 days post-infection) and subjected to necropsy for determination of the number of skeletal nodules containing larvae and to serum collection for antibody determination. Forty uninfected animal were used as controls for the parasitological and serological analyses (five animals sacrificed on different days after the beginning of the infection).

Parasitological analysis. Nodules containing larvae located in skeletal and subcutaneous tissues were counted. The specimens of Lagochilascaris minor (20 larvae/20 nodules) that were collected from individual nodules in five different mice were fixed in $10 \%$ formalin to measure their lengths under a microscope, using computer morphometry. The specimens were morphologically characterized by means of confocal microscopy as L3 larvae, L4 larvae or adult worms, without staining.

Antibody detection. Crude extract antigen (CE) and secreted/excreted antigen preparation (SE) were obtained in accordance with Prudente et al ${ }^{7}$. To detect anti-Lagochilascaris minor antibodies, microtiter ELISA plates (Costar) were coated with antigen $(50 \mu \mathrm{g} / \mathrm{ml})$ and sera were used diluted $1 / 100$ (for IgG, IgM, IgA determination) or 1/50 (for IgE determination). Anti-mouse IgG, IgM and IgA antibodies conjugated to peroxidase, anti-rat IgG conjugated to peroxidase and rat monoclonal-IgG anti-mouse IgE antibodies, were purchased from Sigma. Antibody binding was detected by using ortho-phenylenediamine (OPD) and hydrogen peroxide $\left(\mathrm{H}_{2} \mathrm{O}_{2}\right)$ as chromogen and substrate, respectively. The optimal dilution for the reagents was established in our laboratory. Plates were read at $492 \mathrm{~nm}$ on a Multiskan
Labsystems device. The cutoff value was determined by taking the mean optical density (OD) of ten control subjects plus three standard deviations.

Statistical analysis. The parasitological and immunological parameters were expressed as means and standard deviations. Data from pairs of groups were analyzed using the Mann-Whitney U-test; and data from multiple groups were analyzed using the ANOVA test followed by a multiple comparison test (Dunn's test).

\section{RESULTS}

The numbers of specimens of Lagochilascaris minor recovered from superficial nodules in the skeletal musculature and subcutaneous tissue (each nodule containing one parasite) presented similar profiles in BALB.xid and BALB/c mice, at the start of the experimental period. However, the numbers of parasites recovered from BALB/c mice 150, 180 and 210 days after infection were significantly higher than the numbers presented by BALB.xid-infected mice $(\mathrm{p}<0.05)$ (Figure 1A). The lengths of the parasites recovered were determined by computer morphometry, 30 to 120 days after infection, and specimens of lengths ranging from 8.2 to $13.7 \mathrm{~mm}$ were found. They were further morphologically characterized as L3, L4 or adult parasites. The lengths of the parasites recovered from $B A L B / c$ mice were similar to those seen among specimens recovered from BALB. xid mice, throughout the study period (Figure 1B).

All of the mice orally inoculated with Lagochilascaris minor eggs became infected. They presented macroscopically visible nodules in the skeletal muscles, particularly in the footpads and cervical region, and less frequently, in the liver and lungs, 45 days after infection. Small nodules recovered from the mice always presented live third-stage larvae with motility, characterized by the absence of a post-labial groove (Figure 2A). Some fourth-stage larvae, with well-developed lips separated from the rest of the body by a post-labial groove, were viewed in both mice strains, 180 days after infection. Nevertheless, $20 \%$ of the infected mice presented four to ten large nodules containing individually encysted adult worms, showing lip margins extending laterally beyond the collar with deep post-labial grooves (Figure 2B).

We found a marked difference in the pattern of the antibody response elicited in BALB/C and BALB.xid-infected mice for both the crude extracted and the secreted/excreted antigens of Lagochilascaris minor: the level of antibodies to SE antigens was always larger. IgM antibodies to anti-CE and anti-SE antigens were detected 90 to 210 days after infection in the $\mathrm{BALB} / \mathrm{c}$ infected mice (cutoff $\mathrm{OD}=0.25 \mathrm{~nm}$ ), but were absent from the BALB.xid infected animals (Figures 3A and 3B). Specific IgG antibodies were also detected 90 to 210 days after infection (cutoff OD $=0.3 \mathrm{~nm}$ ) in both lineages, but BALB/c infected mice presented higher levels of IgG, particularly against the SE antigen (Figures 3C and 4D). On the other hand, when the SE antigen was used, the levels of IgA antibodies became positive from 45 to 210 days after infection (cutoff $\mathrm{OD}=0.2 \mathrm{~nm}$ ) in $\mathrm{BALB} / \mathrm{c}$ mice. However, BALB.xid mice presented positive levels of IgA antibodies for the CE of the parasite from 45 to 90 days after infection (Figures 3E and 3F). The levels of IgE antibodies remained positive throughout the study period for both lineages of mice (cutoff $\mathrm{OD}=0.05 \mathrm{~nm}$ ), without significant differences between the strains (Figures 3G and 3H). 


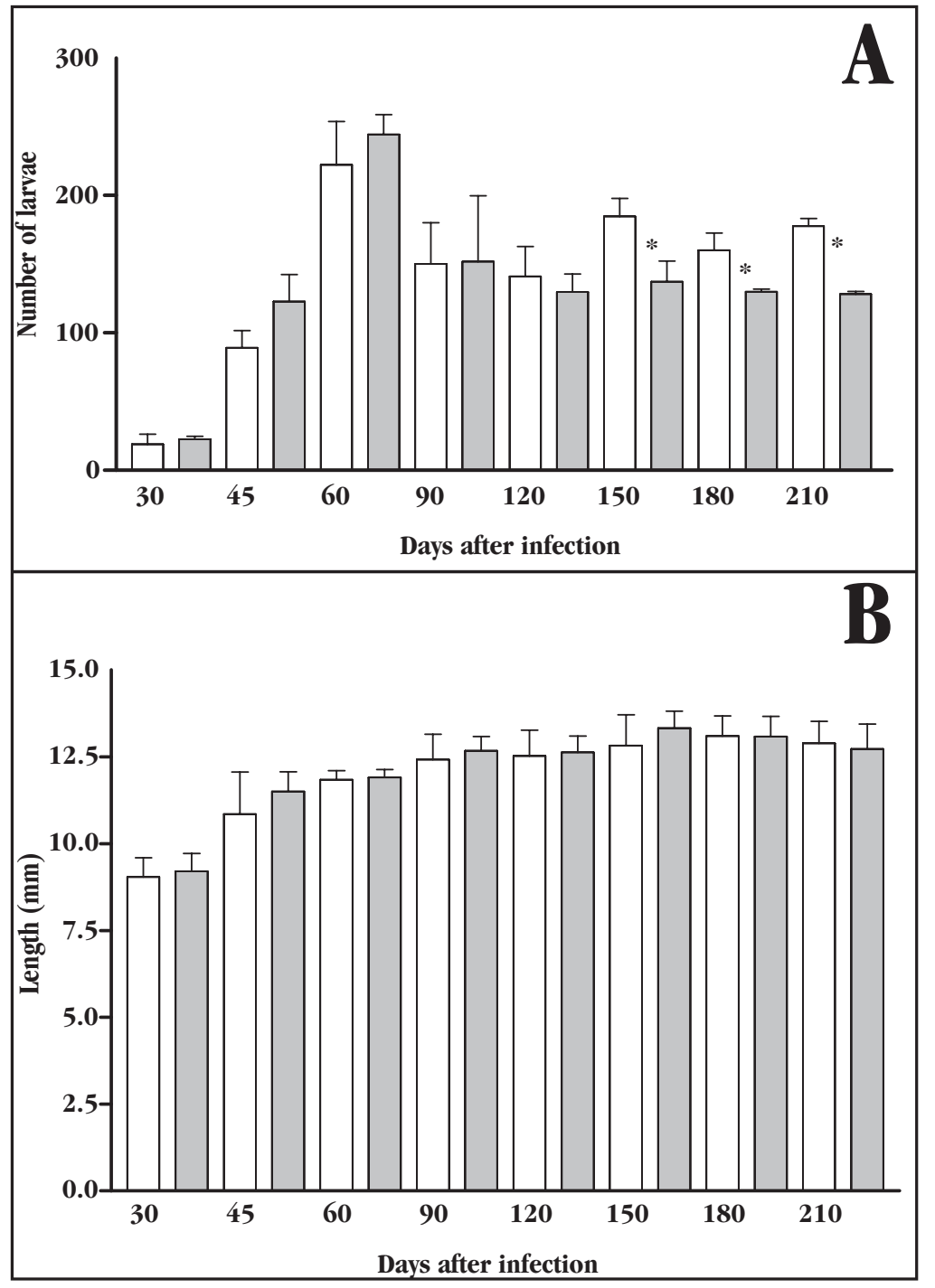

FIGURE 1

Number of larvae recovered from skeletal musculature and subcutaneous tissue from BALB/c mice (white bar) and BALB.xid mice (grey bar) that received infective eggs, from necropsies performed 30 to 345 days after infection $(* \mathrm{p}<0.05)(\mathbf{A})$. Length of larvae obtained from skeletal and subcutaneous tissue of infected BALB/c mice (white bar) and BALB.xid mice (grey bar), 30 to 210 days after infection. Results are expressed as the average of twenty larvae collected from five different mice \pm SD (B). Statistical analysis on the differences was evaluated using the Mann-Whitney test (* $\mathrm{p}<0.05$ ).

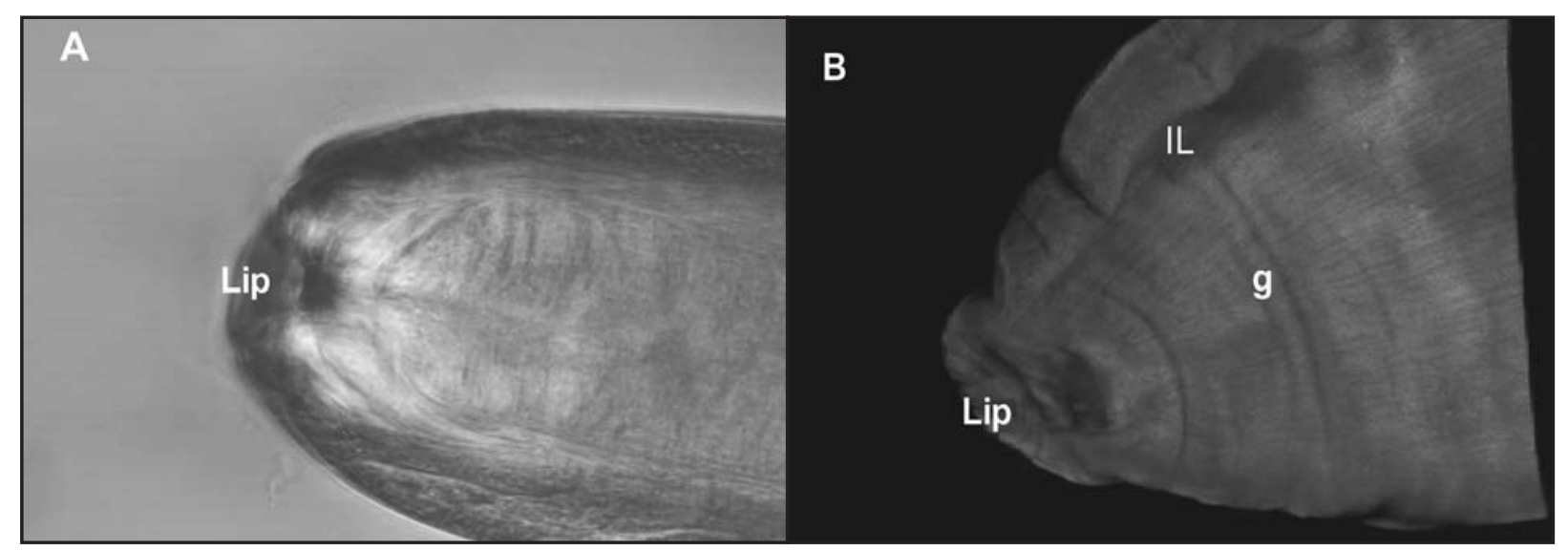

FIGURE 2

L3 larvae of Lagochilascaris minor recovered from the mice on day 60 after infection. Anterior end showing lip with absence of interlabia (IL) and post-labial groove (g), in a confocal image (A). Anterior end of adult parasite recovered 210 days after infection showing lips separated with interlabia (IL) and a post-labial groove (g) (B). Z-series were acquired by confocal microscopy and rasterized using Zeiss LSM image browser. 


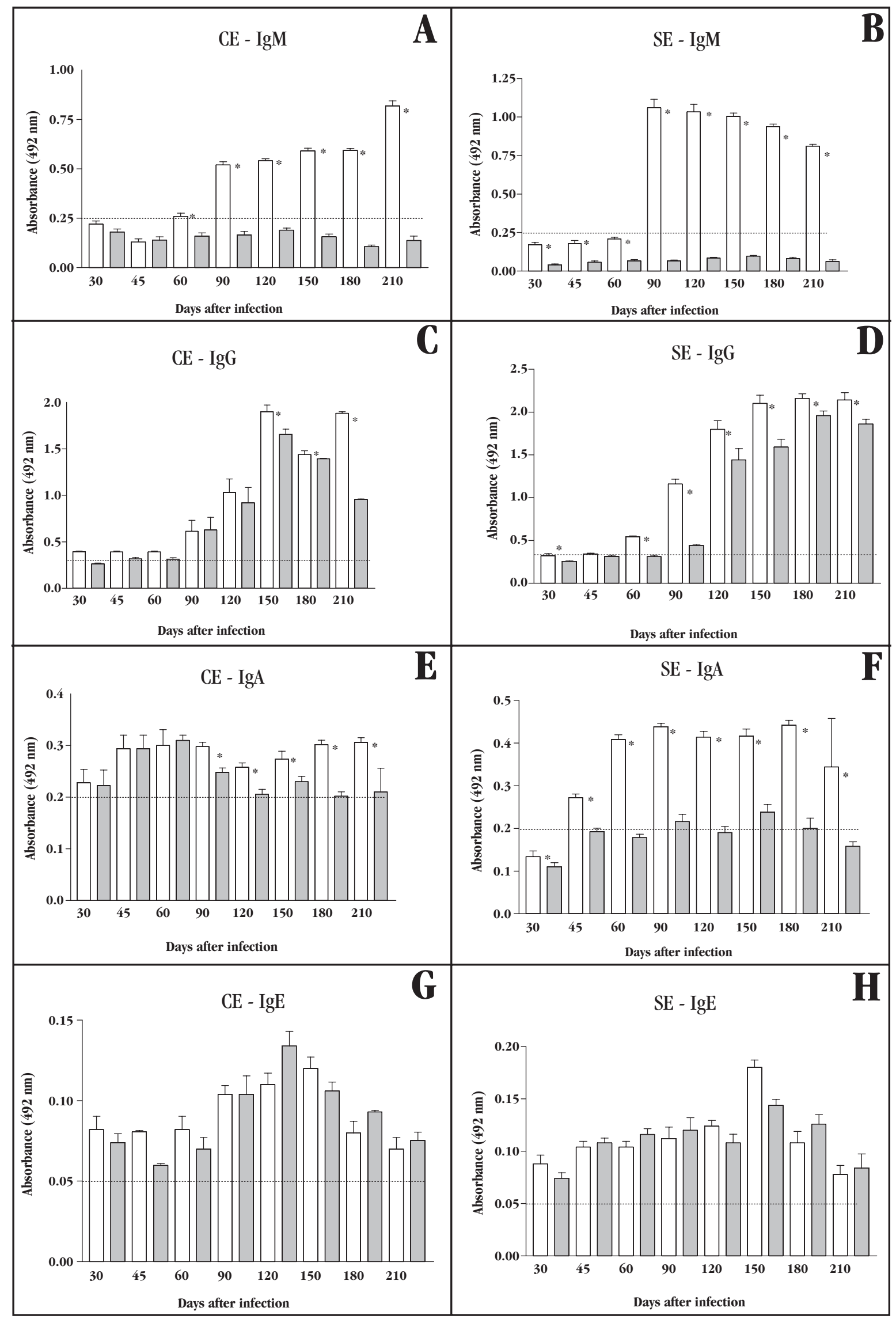

FIGURE 3

Kinetics of immunoglobulin isotypes according to ELISA in BALB/c mice (white bar) and BALB.xid mice (grey bar) infected with Lagochilascaris minor, against the crude extract (CE) or the secreted/excreted antigen (SE). IgM isotype (A-B); IgG isotype (C-D); IgA isotype (E-F); IgE isotype (G-H). Results are expressed as average of five mice \pm SD (*p dd 0.05$)$. 


\section{DISCUSSION}

This report presents evidence suggesting that the absence of B1 cells, along with low production of antibodies in BALB.xid mice infected with Lagochilascaris minor, influences the numbers of parasites recovered from subcutaneous and skeletal musculature tissues during infection, since these numbers were higher in $\mathrm{BALB} / \mathrm{c}$ mice than in BALB.xid mice, 150 days after infection.

Mice are described in the literature as intermediate hosts for Lagochilascaris minor, presenting only third-stage larvae (L3) measuring 6 to $8 \mathrm{~mm}$ in length ${ }^{410}$. Interestingly, L3 larvae recovered 45 days after infection from both infected strains of mice presented lengths of more than $10 \mathrm{~mm}$, i.e. bigger than the sizes of $\mathrm{L} 3$ larvae described in the literature. In both BALB/c and BALB.xid mice, some $\mathrm{L} 4$ larvae and a few adult parasites were also detected. Only one adult parasite was observed in each nodule, thus preventing reproduction and egg elimination. In fact, in a previous paper, we described the presence of $\mathrm{L} 4$ larvae and adult parasites in experimental lagochilascariosis in $\mathrm{C} 57 \mathrm{BL} / 6 \mathrm{mice}^{2}$.

$\mathrm{B} 1$ cells usually interact with antigens that present repetitive epitopes (TI-2), producing great amounts of IgM, IgA and IgG3. However, because BALB.xid mice have fewer B1 cells, they cannot significantly recognize TI-2 antigens and, as a result, they produce low amounts of IgA, IgM and IgG3. In fact, the BALB.xid mice did not have any B1a cells (IgM(hi); CD45(lo); CD23-), but B1b lymphocyte subsets $(\mathrm{CD} 11 \mathrm{~b}+)$ were present, albeit at a lower frequency than that found in their normal counterparts ${ }^{8}$.

The levels of IgA and IgE antibodies were the first ones to turn positive after infection (30-45 days after infection) and these remained positive throughout the study period, thereby indicating the importance of IgE and IgA for detecting recent infection in rodents. It is important to remember that eosinophils present the receptor for IgA, thus indicating early participation of this isotype of immunoglobulin in allergy and helminth infections ${ }^{5}$. However, the specific IgE antibodies presented similar profiles in the two strains throughout the study period, thus indicating that IgE was not responsible for the different susceptibilities of BALB/c and BALB.xid mice to Lagochilascaris minor infection.

The correlation between $B$ cell activation and lesion progress in immunocompetent mice has been well documented. It has been shown that in the absence of functional B cells and antibodies, mice infected with Leishmania amazonensis developed delayed disease with smaller lesions ${ }^{6}$.
We consider that these initial studies are very significant. It will be important not to neglect the participation of B cells in experimental lagochilascariosis, given that cytokine profiles need to be investigated in experimental infection because BALB.xid mice are good producers of IFN $\gamma$.

\section{ACKNOWLEDGEMENT}

The authors would like to thank Dr. Toshie Kawano for help in the confocal analysis and for excellent technical assistance, and American Journal Experts for the English language review. This study was supported by the Research Support Foundation of the State of Goiás.

\section{REFERENCES}

1. Fraiha H, Leão RNQ, Costa FSA. Lagochilascariase humana e dos animais domésticos. Veterinary International Zoonoses 1: 25-33, 1989.

2. Freitas JG, Prudente MFS, Spadafora-Ferreira M, Junqueira-Kipnis AP, Cândido de Paula E, Tambourgi DV, Lino-Junior RS, Carvalhaes MS. Lagochilascaris minor: experimental infection of $\mathrm{C} 57 \mathrm{BL} / 6$ and $\mathrm{BALB} / \mathrm{c}$ isogenic mice reveals the presence of adult worm. Experimental Parasitology 119: 325-331, 2008.

3. Oliveira JA, Barbosa CA, Vieira MA, Fiorini MO, Campos DMB. Isolado de Lagochilascaris minor: procedimentos para obtenção de ovos infectantes. Revista de Patologia Tropical 31: 121-128, 2002.

4. Paço JM, Campos DMB, Araújo de Oliveira J. Wild rodents as experimental intermediate hosts of Lagochilascaris minor Leiper, 1909. Memórias do Instiruto Oswaldo Cruz 94: 441-449, 1994.

5. Pleass RJ, Lang ML, Kerr MA, Woof JM. IgA is a more potent inducer of NADPH oxidase activation and degranulation in blood eosinophils than IgE. Molecular Immunology 44: 1401-1408, 2007.

6. Popi AF, Lopes JD, Mariano M. Interleukin-10 secreted by B1 cells modulates the phagocytic activity of murine macrophages in vitro. Journal of Immunology 113: 348-354, 2004.

7. Prudente MFS, Lima KC, Carvalhaes MS. Hematological, serum biochemical and serological profile of Felis domesticus with experimental lagochilascariosis. Revista da Sociedade Brasileira de Medicina Tropical 41: 496-501, 2008.

8. Riggs J, Howell K, Matechin B, Matlack R, Pennello A, Chiasson R. X-chromosomelinked immune-deficient mice have B-1b cells. Immunology 108: 440-51, 2003 .

9. Semerene AR, Lino-Junior RS, Oliveira JA, Magalhães AV, Stefani MMA, Barbosa AP, Campos DMB. Experimental lagochilascariosis: histopathological study of inflammatory response to larval migration in the murine model. Memórias do Instituto Oswaldo Cruz 99: 393-398, 2004.

10. Volcan GS, Medrano CE, Payares G. Experimental heteroxenous cycle of Lagochilascaris minor Leiper, 1909 (Nematoda: Ascarididae), in white mice and cats. Memórias do Instituto Oswaldo Cruz 87: 535-532, 1992. 